\title{
IMPLIKASI PRINSIP MOST FAVOURED NATION DALAM UPAYA PENGHAPUSAN HAMBATAN PEDAGANGAN INTERNASIONAL
}

\author{
Prawitra Thalib, SH.,MH. \\ Anwar Rachman dan rekan, prawitra_36888@yahoo.com
}

\begin{abstract}
Barriers on international trade is one of the complicated problems, therefore the efforts to eliminate it still have been doing by the countries around the world. Meanwhile the discrimination factor in international trade is one of the most important issue that can hamper trade and economic progress of a country, because discrimination can cause uneven distribution of goods and services which are aimed to prosper the people of a country. Therefore, the equal treatment among countries in international trade or as known as Most Favoured Nation Priciple, is crucial. This principle emphasizes equal treatment in every country so trading activity will be expected the same in any country. This Principle can automatically remove the obstacles that might occur in the international trade, by maximizing the role of the World Trade Organization in the International Trading arena.
\end{abstract}

Key words: Most Favoured Nation, Discrimination, Trade.

\begin{abstract}
Abstrak
Hambatan dalam perdagangan internasional merupakan salah satu permasalahan yang komplikatif, oleh karena itu upaya untuk menghapuskan terus diupayakan oleh negaranegara yang ada di dunia, adapun faktor diskriminasi dalam perdagangan internasional merupakan salah satu isu terpenting yang dapat menghambat kegiatan perdagangan dan kemajuan perekonomian suatu negara, karena diskriminasi dapat menyebabkan tidak meratanya arus perputaran barang dan jasa yang bertujuan memakmurkan rakyat di suatu negara. Oleh karena itu penting sekali bahwa dalam kegiatan harus selalu mengedepankan perlakuan yang sama antar negara yang terkait dalam kegiatan perdagangan tersebut, atau yang lebih dikenal dengan istilah prinsip Most Favoured Nation. Prinsip ini mengedepankan perlakuan yang sama pada setiap negara yang melakukan kegiatan perdagangan sehingga diharapkan dengan adanya perlakuan yang sama tersebut dapat secara otomatis menghilangkan hambatan-hambatan yang terjadi dalam dunia perdagangan, dengan memaksimalkan peranan World Trade Organization dalam kancah perdagangan dunia.
\end{abstract}

Kata Kunci: Most Favoured Nation, Diskriminasi, Perdagangan. 


\section{Pendahuluan}

Perdagangan bilateral maupun merupakan salah satu faktor terpenting dalam kegiatan internasional, betapa tidak hal tersebut dikarenakan suatu negara tidak dapat memenuhi kebutuhan dalam negerinya secara sepihak tanpa adanya bantuan dari pihak lain, oleh karena itu kegiatan perdagangan antar negara sangatlah diperlukan dengan tujuan supaya bisa saling menguntungkan antar negara. Tidak hanya itu permasalahan dalam bidang perdagangan juga dapat menyebabkan konflik internasional yang berkepanjangan, sejarah telah membuktikan bahwa dua permasalahan dalam bidang perdagangan yang terjadi pada tahun 1930an diindikasikan sebagai salah satu faktor pemicu terjadinya perang dunia kedua.

Mengenai permasalahan yang pertama adalah kebijakan perdagangan yang proteksionistis, yang mana pada saat itu negara-negara enggan meliberalisasi kebijakan dagangnya, karena negara-negara tersebut lebih cenderung untuk bilateralisasi yaitu membuat perjanjian bilateral dengan suatu negara lain. Sedangkan permasalahan yang kedua adalah kebijakan tarif yang masih cukup tinggi yang mengakibatkan hambatan terhadap perdagangan dunia, karena negara-negara tersebut secara tidak langsung telah menghalangi masuknya produk impor dalam negerinya. ${ }^{1}$

Oleh karena pentingnya masalah perdagangan ini dan dampak yang

${ }^{1}$ Baskara T. Wardaya, Indonesia Melawan Amerika Konflik Perang Dingin (1953-1963), Cetakan Pertama, Galang Press, Yogyakarta, 2008, h. 11-12 ditimbulkannya maka sudah pasti setiap negara menginginkan perdagangan yang fair dan adil, untuk mewujudkan hal ini sekaligus mencegah terulangnya dua permasalahan yang pernah terjadi pada tahun 1930an diperlukanlah suatu aturan pokok dalam kegiatan perdagangan antar negara, yang dalam hal ini adalah tidak adanya diskriminasi bagi setiap negara yang melakukan perdagangan tersebut.

Pada dasarnya prinsip non diskriminasi tersebut menuntut adanya perlakuan yang sama bagi negara-negara internasional yang melakukan kegiatan perdagangan sehingga tercipta praktek perdagangan yang fair dan adil. Mengenai perlakuan yang sama bagi setiap negara dikenal dengan prinsip Most Favoured Nation.

Mengenai pelaksanaan prinsip ini dalam kegiatan perdagangan internasional ternyata tidaklah mudah dan harus ada lembaga internasional tertentu yang mengawasi pelaksanaan prinsip Most Favoured Nation ini. Sehingga dapat menghilangkan adanya diskriminasi dalam perdagangan Internasional dan dapat mencegah terulangnya kembali permasalahan perdagangan yang terjadi pada tahun 1930an, oleh karena itu penulis merasa tertarik untuk membahas tentang kedudukan serta peranan dan fungsi prinsip Most Favoured Nation ini dalam World Trade Organization sebagai organisasi multilateral dalam perdagangan dunia. apa karakteristik dari prinsip Most Favoured Nation dalam World Trade Organization dalam melaksanakan tugas dan fungsinya di bidang perdagangan internasional? 


\section{Pembahasan}

Isu mengenai pembentukkan organisasi perdagangan dunia sudah mulai dibicarakan pada saat penandatanganan Piagam Atlantik (Atlantic Charter) pada bulan Agustus 1941. Piagam Atlantik tersebut selain menggaris bawahi pentingnya menumbuhkan semangat kebebasan dan kemerdekaan, bagi negaranegara di dunia ketiga juga memiliki tujuan untuk menciptakan sistem perdagangan yang berdasarkan pada prinsip non diskriminasi dan kebebasan tukar menukar barang dan jasa. $^{2}$

Tidak hanya itu kehadiran suatu lembaga perdagangan dunia juga dirasakan perlu eksis disamping adanya Bank Dunia (World Bank) dan International Monatery Fund (IMF), Pada mulanya lembaga yang dimaksud tersebut adalah suatu International Trade Organisation (ITO), sehingga diharapkan dengan adanya ketiga lembaga ini dapat saling membantu bekerja sama demi mencapai praktek perdagangan dunia yang saling menguntungkan dan tanpa diskriminasi apapun.

Mengenai fungsi dan peranan yang dapat dilakukan dengan adanya tiga lembaga tersebut adalah Bank Dunia (world Bank) menangani masalah rekonstruksi pembangunan dan ekonomi, International Monatery Fund (IMF) menangani masalah keuangan dan International Trade Organisation (ITO) menangani urusan perdagangan internasional.

Dalam realitanya mewujudkan suatu International Trade Organisation (ITO)

\footnotetext{
2 Lihat, Ibid, hal 21
}

tidaklah semudah yang dibayangkan, hal tersebut dikarenakan cakupan ruang lingkup yang luas, keinginan dari masingmasing negara maupun kepentingan dari setiap negara yang bersangkutan, sehingga keinginan untuk mewujudkan International Trade Organisation (ITO) tersebut harus melalui beberapa tahapan-tahapan yang tidak sedikit dan memakan waktu yang lama.

Mengenai tahapan-tahapan pembentukan organisasi perdagangan dunia tersebut dapat dilihat dalam pembahasan berikut:

1. Perundingan Tahap Pertama

a) Usul pembentukkan ITO ini pertama kali diusulkan oleh Amerika Serikat pada tanggal 6 Desember 1944, usul tersebut pada awal dibentuknya PBB disambut baik oleh Economic and Social Council (ECOSOC) oleh karena itu maka dibentuklah suatu komisi untuk membahas masalah ini, sidang komisi tersebut dilakukan dari tanggal 18 Oktober sampai 26 Desember 1945 dan menghasilkan rancangan Piagam London, namun para anggota peserta pertemuan ini gagal mencapai sepakat untuk mengesahkan piagam tersebut. ${ }^{3}$

b) Pertemuan di Lake Success New York Amerika Serikat, yang berlangsung dari tanggal 20 Januari sampai 25 Febuari 1946, pertemuan ini diikuti oleh Amerika Serikat, Kanada, Inggris,

${ }^{3}$ Lihat, Hata; Perdagangan internasional dalam system GATT dan WTO-Aspek-aspek Hukum dan Non Hukum, Cetakan Pertama, PT Refika Aditama, Bandung, September 2006, hal 130 
Perancis dan negara-negara Benelux. Komisi ini bertugas untuk merancang suatu organisasi perdagangan baru. Akan tetapi ternyata pertemuan ini hanya membahas hal-hal yang biasa

c) Perundingan di Jenewa Swiss pada tanggal 10 April 1947 sampai 30 Oktober 1947, di mana mulai dari tanggal 10 April sampai 22 Agustus panitia komisi membuat rancangan piagam Internasional Trade Organisation (ITO), perundingan ini merupakan perundingan yang penting karena menghasilkan konsesi timbal balik dibidang tarif (reciprocal tariffs concession) yang dicantumkan dalam GeneralAgreementonTariffsandTrade (GATT) yang ditandatangani pada tanggal 30 oktober 1947 dan selain itu berdasarkan persyaratan-persyaratan protokol tanggal 30 Oktober 1947 tersebut, GATT ditetapkan sebagai suatu kesepakatan umum sementara sejak tanggal 1 Januari 1948 hingga dibentuknya suatu Internasional Trade Organisation (ITO). ${ }^{4}$

d) Sejakawal dibentuknyaGATT tersebut pada tahun 1947, pada dasarnya ada tiga tujuan utama yang hendak dicapai yang antara lain adalah: ${ }^{5}$

(1) Memperjuangkan terciptanya perdagangan internasional yang bebas dan jujur.

(2) Menstabilkan sistem perdagangan

(3) Memperjuangkan penurunan

4 Ibid, h. 14-15

5 Imam Sjahputra, Hak Atas Kekayaan Intelektual (Suatu Pengantar), Harvarindo, 2007, h.17 dan penghapusan hambatan perdagangan baik yang berupa tarif dan yang bukan tarif.

Dan ternyata dalam prakteknya ketiga tujuan dasar dari GATT tersebut berkembang menjadi : 6

(1) Meningkatkan taraf hidup umat manusia.

(2) Meningkatkan kesempatan kerja

(3) Meningkatkan pemanfaatan kekayaan alam dunia

(4) Meningkatkan produksi dan tukar menukar barang

Sehingga dalam mencapai tujuantujuannya tersebut GATT secara langsung maupun tidak langsung juga memiliki fungsi-fungsi yang antara lain adalah: ${ }^{7}$

(1) Sebagai perangkat ketentuan aturan multilateral.

(2) Sebagai forum negosiasi.

(3) Sebagai forum penyelesaian sengketa dagang.

2. Perundingan Tahap 2

Dalam perkembangannya GATT telah mengadakan delapan perundingan atau lebih dikenal dengan istilah putaran (round), putaran tersebut telah dilakukan dalam kurun waktu yang lama dan dilakukan di berbagai negara serta menghasilkan banyak ketentuan-ketentuan baru bagi materi dari GATT itu sendiri.

\footnotetext{
${ }^{6}$ Huala Adolf, Hukum Dagang Internasional (GATT): Persetujuan Umum Mengenai Tarif dan Perdagangan, Badan Penerbit Islam, Jakarta, 2005, h. 2. 7 Ibid
} 
Mengenai putaran-putaran yang pernah dilaksanakan olah GATT antara lain adalah :
a. Geneva Round (1947)
b. Annecy Round (1949)
c. Torquay Round (1951)
d. Geneva Round (1956)
e. Dillon Round (1960-1961)
f. Kennedy Round (1964-1967)
g. Tokyo Round (1973-1979)
h. Uruguay Round (1986-1993)

Adapun dari putaran-putaran tersebut ada beberapa putaran yang dianggap penting dan menghasilkan kesepakatan yang signifikan yang antara lain adalah:

\section{a. Kennedy Round (1964-1967)}

Pada prinsipnya putaran ini mengajak para negara peserta untuk menandatangani the 1967 Agreement on Implementation on Article VI, yang mengatur mengenai larangan praktek dumping atau yang lebih dikenal dengan istilah Anti Dumping Code. yang pada akhirnya perjanjian tahun 1967 ini mulai disepakati berlaku pada tanggal 1 Juli $1968 .{ }^{8}$

\section{b. Tokyo Round (1973-1979)}

Perjanjian ini mulai berlaku pada tanggal 1 Januari 1980, diantara perjanjian atau Codes yang dihasilkan dalam Tokyo Round tersebut, maka Agreement on Interpretation and Application on Articles VI, XVI and XXIII on the General Agreement on Tariffs and Trade (GATT), yang biasa disebut Subsidies Code tersebutlah

\footnotetext{
${ }^{8}$ Ibid,h.39.
}

yang merupakan perjanjian yang paling kompleks dan penting diantara perjanjian-perjanjian multilateral ini. ${ }^{9}$

Yang membedakan Subsidies Code dengan Codes sebelumnya adalah dari segi upaya penyelesaian sengketanya, dimana dalam Subsidies Code terdapat sebuah komite yang disebut Committee on Subsidies and Countervailing Measures yang terdiri dari wakilwakil setiap negara penandatangan perjanjian ini, tugas dari komite ini adalah melakukan konsiliasi dan pembentukkan panel. Sedangkan proses dari pelaksanaan tugas komite tersebut adalah, apabila usaha-usaha konsiliasi gagal maka penandatangan perjanjian ini (anggota komite) dapat meminta komite untuk membentuk panel. Yang akan menyerahkan temuannya kepada komite dan komite akan mempertimbangkan laporan dari panel tersebut. sebagai rekomendasi untuk penyelesaian sengketa, namun apabila rekomendasi komite tersebut tidak dihiraukan maka komite dapat membenarkan diambilnya suatu tindakan batasan. ${ }^{10}$

\section{c. Uruguay Round (1986-1993)}

ini merupakan perundingan GATT yang kedelapan dan perundingan yang paling banyak memakan waktu sejak didirikannya GATT. Uruguay Round ini dimulai pada tanggal 20 September tahun 1986 di Punta Del Este Uruguay.

\footnotetext{
${ }^{9}$ Hata, Loc Cit.

${ }^{10}$ Ibid h. 131-132
} 
Tujuan dari perundingan ini adalah: ${ }^{11}$

(1) Melakukan penafsiran baru terhadap beberapa Pasal GATT 1947.

(2) Menambah cakupan GATT dengan perjanjian tentang hasil-hasil pertanian, perjanjian tentang tekstil dan pakaian jadi, perdagangan, jasa, perjanjian tentang hak milik intetletual, perjanjian tentang kebijakan penanaman modal yang berkaitan dengan perdagangan, kesepakatan baru mengenai aturan umum perdagangan dan pembentukkan Multilateral Trade Organisation (MTO).

(3) Meningkatkan peranan GATT dan memperbaiki sistem perdagangan multilateral berdasarkan prinsipprinsip dan ketentuan GATT.

(4) Meningkatkan ketanggapan sistem GATT terhadap perkembangan situasi perekonomian dunia dan teknologi tinggi.

(5) Mengembangkan suatu bentuk kerjasama pada tingkat internasional untuk mempererat hubungan antara kebijakan perdagangan dan kebijakan ekonomi lainnya.

sebagai pelaksanaan dari hasil perjanjian dalam putaran Uruguay tersebut maka pada tanggal 15 April 1994 ditandatanganinya Marrakesh Agreement Establishing The World Trade Organization di Marrakesh ${ }^{11}$ Imam Sjahputra, Op Cit, h. 18.
Maroko sekaligus menandai berakhirnya putaran Uruguay.

Hingga pada akhirnya sebagai konsekuensi ditandatanganinya Marrakesh Agreement Establishing The World Trade Organization, para negara peserta menyepakati persetujuan pembentukkan organisasi perdagangan duniaWTObeserta seluruh lampirannya yang mulai diberlakukan pada tanggal 1 Januari 1995.

Oleh karena itu berdasarkan uraian diatas dapat disimpulkan bahwa WTO tidak lain adalah GATT 1947 yang telah mengalami improvisasi dan perkembangan, oleh karena itu sebagai bentuk improvisasi dan perkembangan, maka GATT 1994 adalah berupa tambahan-tambahan kesepakatan maupun perundingan bilateral yang terjadi antara para negara peserta GATT, sehingga dapat dikatakan bahwa muatan dari GATT 1994 tersebut antara lain adalah :

1. Perjanjian-Perjanjian GATT yang disahkanpadatanggal30Oktober1947, yang ditambah atau diamandemen oleh keputusan-keputusan maupun hasil dari perundingan-perundingan hingga dibentuknya WTO pada tahun 1994.

2. Perjanjian-Perjanjian yang memuat kesepakatan tariff, yang di buat sebelum terbentuknya WTO, yaitu perjanjian-perjanjian mengenai aksesi bagi negara-negara yang menjadi anggota GATT, termasuk juga keputusan mengenai penanggalan yang diberikan berdasarkan Pasal 


\section{GATT 1947.}

Selain itu dalam Penjelasan UndangUndang Nomor 7 Tahun 1994 Tentang Pengesahan Agreement Establishing The World Trade Organization (Persetujuan Persetujuan Pembentukkan Organisasi Perdagangan Dunia ), juga disebutkan mengenai tujuan dari diadakannya pembentukkan organisasi perdagangan dunia ini yang antara lain adalah :

1. Tujuan umum, secara umum tujuan Putaran Uruguay adalah untuk menciptakan sistem perdagangan internasional yang lebih bebas dan adil dengan tetap memperhatikan kepentingan negara-negara berkembang pada khususnya.

2. Tujuan khusus, yang mana tujuan umum tersebut dijabarkan lebih lanjut lagi sebagai berikut:

a) Akses pasar (access to market) bagi produk-produk ekspor melalui upaya penurunan dan penghapusan tarif bea masuk, pembatasan kuantitatif maupun hambatanhamabatan perdagangan non tarif lainnya.

b) Memperluas cakupan produk perdagangan internasional termasuk perdagangan dibidang jasa, mpengaturan mengenai aspek-aspek dagang dari hak atas kekayaan intelektual, dan kebijaksanaan investasi yang berkaitan dengan perdagangan.

c) Peningkatan peranan GATT dalam mengawasi pelaksanaan komitmen yang telah dicapai dan memperbaiki system perdagangan multilateral berdasarkan prinsip-prinsip dan ketentuan yang tertuang dalam GATT.

d) Peningkatan sistem GATT supaya lebih tanggap terhadap perkembangan situasi perekonomian serta mempererat hubungan GATT dengan organisasi-organisasi internasional yang terkait khususnya dengna prospek perdagangan produkproduk berteknologi tinggi.

e) Pengembangan bentuk kerjasama pada tingkat nasional maupun internasional dalam rangka memajukan kebijakan perdagangan dan kebijakan ekonomi lain yang mempengaruhi pertumbuhan dan perkembangan perekonomian, melalui usaha memperbaikai sistem moneter internasional.

Pada dasarnya Pasal-Pasal dalam ketentuan GATT ini meliputi beberapa prinsip-prinsip pokok dalam melakukan praktek perdagangan internasional. Dalam hal ini para ahli menafsirkan beberapa prinsip-prinsip GATT yang masing-masing memiliki karakteristik tersendiri, prinsipprinsip tersebut antara lain adalah: ${ }^{12}$

1. Prinsip perlakuan yang sama bagi setiap negara atau Most Favored Nation (MFN)

2. Prinsip National Treatment

${ }^{12}$ Huala Adolf; Op Cit, hal 19-29 
3. Prinsip Larangan Restriksi Kuantitatif

4. Prinsip Perlindungan melalui tarif

5. Prinsip Transparansi

6. Prinsip Resiprositas
7. Perlakuan khusus bagi negara berkembang

Selain itu juga ada yang pemikiran yang sedikit berbeda mengenai prinsip-prinsip GATT ini yang antara lain adalah: ${ }^{13}$

\section{Most Favored Nation}

\section{Protection Through Tariifs}

\section{A Stable Basis For Trade}

\section{Promoting Fair Compentition}

\section{Quantitatives Restriction of Impor}

Most Favoured Nation (MFN) yaitu sebagaiprinsiputamadariGeneralAgreement of Tariff and Trade (GATT). Pada intinya prinsip ini bertujuan utnuk menghilangkan diskriminasi terhadap praktek perdagangan internasional dan juga dengan adanya prinsip ini maka akan menjamin dan melindungi hak-hak dari negara-negara berkembang dalam mendapatkan keuntungan dari kondisi-kondisi perdagangan terbaik yang dinegosiasikan oleh negara-negara berkembang.

Prinsip ini adalah prinsip utama dan yang paling penting dari GATT, betapa tidak setiap pendapat para ahli pasti menempatkan prinsip ini pada urutan pertama dan tidak hanya itu prinsip ini pun juga menjamin adanya suatu persaingan yang sehat dalam setiap kegiatan perdagangan dunia dan

\footnotetext{
${ }^{13}$ Imam Sjahputra, Op Cit, h. 17-18.
}

juga menjamin bahwa setiap negara akan mendapatkan perlakuan dan kesempatan yang sama dalam kegiatan perdagangan dunia tanpa adanya diskriminasi.

Indonesia sendiri pernah digugat oleh Amerika Serikat, Uni Eropa dan Jepang dalam sengketa the auto. Yang mana dalam sengketa tersebut Indonesia diklaim telah memberikan perlakuan diskriminatif yang merugikan Amerika Serikat, Uni Eropa dan Jepang, karena Indonesia memberikan keringanan pajak kepada suatu pemegang merek dari Korea Selatan. ${ }^{14}$

Tidak hanya itu prinsip ini pun diberlakukan tanpa memandang struktur sosial-politik dan ekonomi dari negara peserta, prinsip ini pun juga memberikan landasan bagi negara maju dan negara berkembang, negara industri maupun agraris, serta prinsip ini dalam batas-batas tertentu antara sistem bebas dan ekonomi terpimpin. ${ }^{15}$

Akan tetapi sekalipun prinsip Most Favoured Nation (MFN) ini merupakan prinsip yang utama dan terpenting dalam General Agreement on Tariffs and Trade (GATT), dalam keadaan atau kondisi tertentu ketentuan-ketentuan dalam General Agreement on Tariffs and Trade (GATT) juga memperbolehkan dilakukannya tindakan pengecualian terhadap prinsip Most Favoured Nation (MFN) ini, mengenai pengecualian terhadap prinsip Most Favoured Nation (MFN) ini dapat dilihat pada uraian dibawah ini:

1. Keuntungan yang diperoleh karena

14 Huala Adolf, Op Cit, h. 32.

15 Hata ; Op Cit, hal 55 
jarak lalu lintas (frontier traffic advantage), tidak boleh dikenakan terhadap anggota GAAT lainnya (Pasal VI). ${ }^{16}$

2. Perlakuan preferensi di wilayahwilayah tertentu yang sudah ada (misalnya kerja sama ekonomi dalam British Commonwealth, the French Union, dan Banelux Economic Union) tetap boleh terus dilaksanakan namun tingkat batas preferensinya tidak boleh dinaikkan.

3. Anggota-anggota GAAT yang membentuk suatu Customs Union atau Free Trade Area yang memenuhi persyaratan Pasal XXIV GAAT tidak harus memberikan perlakuan yang sama kepada negara anggota lain.

4. Restrictions to Safeguards the Balance of Payments (Article XII)

Tindakan ini merupakan tindakan pengecualian dari prinsip MFN yang terdapat dalam GATT karena dalam Pasal tersebut suatu negara boleh untuk menerapkan pembatasan terhadap masuknya produk impor demi mengamankan neraca pembayarannya,

5. Exceptions to the General Rule of Non-Discriminations (Article XIV)

Merupakan suatu pengecualian yang dapat mengesampingkan prinsip non diskriminasi dalam restriksi suatu produk.

6. Emergency action on Importd of particular Products (Article XIX)

\footnotetext{
${ }^{16}$ Lihat, Huala Adolf; Op Cit, hal 21
}

Pasal ini mengatur bahwa dapat dilakukan tindakan darurat atas impor produk-produk tertentu apabila kehadiran produk impor tersebut telah mengakibatkan terpukulnya produsen dalam negeri.

\section{General Exception (Article XX)}

Pada prinsipnya General Exception atau pengecualian umum ini sama dengan tindakan darurat, akan tetapi sebagaimana yang dicantumkan dalam Pasal XX ini, pengecualian umum tersebut dilakukan dalam hal yang berkaitan dengan tindakan yang diperlukan untuk:

a) Melindungi moral masyarakat.

b) Melindungi kehidupan atau kesehatan manusia, hewan atau tanaman.

c) Impor atau ekspor emas atau perak.

d) Perlindungan terhadap hak atas kekayaan intelektual

e) Produk-produk yang berasal dari hasil kerja para narapidana.

f) Perlindungan kekayaan nasional, kesenian, sejarahatau purbakala.

g) Konservasi kekayaan alam yang dapat habis.

h) Dalam kaitannya dengan adanya kewajiban-kewajiban yang timbul dari perjanjian komoditi antar pemerintah dll.

i) Pembatasan terhadap produk ekpor domestik terhadap suatu negara 
juga dapat diberlakukan apabila terdapat ketidak stabilan harga komoditi ekspor tersebut dinegara tujuan ekspornya, pembatasan ini dilakukan hanya sampai harga produk domestik tersebut stabil kembali dan detelah itu tidak lagi diberlakukan pembatasan.

j) Dalam hal penyediaan dan pendistribusian produk harus konsisten terhadap prinsip yang telah ditetapkan.

\section{Security Exception (Article XXI)}

Pasal ini membenarkan suatu negara untuk mengesampingkan prinsipprinsip GATT (termasuk prinsip MFN) dengan alasan keamanan dalam negerinya, yang dalam Pasal ini alasan mengenai keamanan dalam negeri tersebut memiliki kriteria antara lain adalah:

a) Berhubungan dengan kondisi dari barang tersbut.

b) Berhubungan dengan perdagangan senjata, amunisi dan hal-hal lain yang berhubungan dengan perang seperti pengadaan barang-barang untuk membentuk suatu kekuatan militer ilegal.

c) Pada saat terjadi perang atau dalam keadaan darurat.

d) Untuk mencegah pihak-pihak lain untuk mengambil tindakan yang mengatasnamakan Piagam PBB.

Demikianlah pengecualian dari prinsipprinsip MFN dalam GATT, sehingga dapat disimpulkan walaupun prinsip MFN ini pada pokoknya mengikat para anggota WTO dan wajib untuk ditaati, namun dalam keadaan tertentu suatu negara dapat mengesampingkan prinsip MFN ini (sekalipun prinsip MFN ini merupakan prinsip utama dalam GATT), dengan maksud dan tujuan untuk melindungi rakyat, melindungi produksi dalam negeri, untuk menstabilkan neraca pembayaran, untuk alasan moral maupun untuk mencegah timbulnya konflik dalam negeri.

\section{Penutup}

Bahwa pada mulanya World Trade Organization (WTO) hanya berupa kesepakatan umum dalam hal perdagangan dan tariff yaitu General Agreement on Tariffs and Trade (GATT), hingga dalam perkembangannya muncul kebutuhan akan adanya suatu organisasi yang mengikat anggota-anggota General Agreement on Tariffs and Trade (GATT) dalam melaksanakan praktek perdagangan internasional, maka dari itu lahirlah World Trade Organization (WTO). Bahwa sekalipun prinsip Most Favoured Nation adalah prinsip utama dan pokok dalam menciptakan perdagangan tanpa diskriminasi, dalam keadaan maupun dalam kondisi tertentu pengecualian terhadap prinsip ini diperbolehkan bagi negaranegara anggota World Trade Organization (WTO).

Adapun dalam mengawasi praktek perdagangan internasional World Trade Organization (WTO), harus lebih dapat bersikap obyektif dalam melindungi 
negara-negara berkembang, terutama dalam menerapkan perlakukan khusus bagi negaranegara berkembang yang berdampak positif bagi negara berkembang tersebut, sehingga jangan sampai praktek perdagangan internasional ini hanya menguntungkan negara-negara maju dan mengabaikan negara-negara berkembang. Oleh sebab itu Indonesia dalam melaksanakan praktek perdagangan internasional harus dapat lebih banyak membaca peluang pasar untuk melindungi produsen dalam negeri dnegan cara memanfaatkan pengecualianpengecualian yang diatur dalam ketentuanketentuan General Agreement on Tariffs And Trade (GATT).

\section{Daftar Bacaan}

\section{Buku-Buku}

Baskara T Wardaya. Indonesia Melawan Amerika Konflik Perang Dingin (1953-1963. Cetakan Pertama. Galang Press.Yogyakarta. 2008.

Direktorat Perdagangan dan Perindustrian Multilateral. Direktorat Jenderal Multilateral Ekonomi Keuangan dan Pembangunan. Departemen Luar Negeri Republik Indonesia. Sekilas WTO (World Trade Organization). Jakarta. 2002.
Hata. Perdagangan Internasional Dalam Sistem GATT dan WTO-Aspek-aspek Hukum dan Non Hukum. Cetakan Pertama. PT Refika Aditama. Bandung. September. 2006.

Huala Adolf. Hukum Dagang Internasional (GATT): Persetujuan Umum Mengenai Tarif dan Perdagangan. Badan Penerbit Islam. Jakarta. 2005.

Imam Sjahputra. Hak Atas Kekayaan Intelektual (Suatu Pengantar). Harvarindo. 2007.

\section{Peraturan Perundang-undangan}

Republik Indonesia Undang-Undang Nomor 7 tahun 1994 tentang Pengesahan Agreement Establishing on World Trade Organisation (Persetujuan Pembentukkan Organisasi perdagangan Dunia) 
46 Yuridika: Volume 27 No 1, Januari-April 2012 